\title{
Hydrologic and sediment responses to vegetation and soil disturbances
}

\author{
J.H. GIORDANENGO, G.W. FRASIER, AND M.J. TRLICA
}

Authors are former Graduate Research Assistant, Colorado State University, Rangeland Ecosystem Science Dept., Fort Collins, Colo.; Research Hydraulic Engineer (Retired), USDA, Agricultural Research Service, Fort Collins, Colo.; Professor, Colorado State University, Rangeland Ecosystem Science Dept., Fort Collins, Colo. 80523.

\begin{abstract}
Soil erosion has been linked to stream sedimentation, ecosystem degradation, and loss of rangeland productivity. However, knowledge of soil loss, as it affects rangeland productivity or ecosystem sustainability is lacking. We evaluated the effects of 3 levels of vegetation cover reduction $(0,27 \%$, and $43 \%)$ and soil removal $\left(0,12\right.$, and 24 tonnes ha $\left.^{-1}\right)$ on soil surface runoff and sediment yield in a sagebrush [Artemisia tridentata var. vasseyana (Rydb.) Beetle] steppe under simulated rainfall. Time to runoff initiation was affected by the vegetation cover reduction treatments, but not by the soil removal treatments. The $43 \%$ vegetation canopy reduction treatment resulted in a shorter time to runoff initiation than did the $27 \%$ and $0 \%$ canopy reduction treatments $(p=0.002)$. Results from analysis of covariance indicated that vegetation reduction and soil removal did not significantly affect sediment yield or runoff quantities in the first year following treatments. Multiple regression analysis revealed total sediment yield was related to forb cover, sand in the upper soil profile $(0-5 \mathrm{~cm})$, and the amount of bare ground. Time to runoff initiation was positively correlated with slope. Despite the lack of significant treatment differences, we do not conclude that these soil removal and vegetation reduction treatments had no affect on soil surface hydrology and sediment yield. There are numerous studies that show a strong relationship between vegetation reduction and soil erosion. Future research at this site may reveal long-term treatment effects that were not apparent in first year results.
\end{abstract}

Key Words: rainfall simulation, erosion, runoff, hydrology, sagebrush steppe

Soil erosion is a major problem throughout the world (Meyers 1984, Pimentel et al. 1995) and has been recognized as a problem in the United States since the early 1900's (Sampson 1918). In the United States, an estimated 4.4 billion tonnes of soil are eroded by wind and water every year (Bills and Heimlich 1984). In many cases, these soil losses lead to increased sediment loads in streams and rivers which can reduce productivity of aquatic ecosystems, shorten the life span of ponds and reservoirs

This research was funded by the United States Department of Agriculture Agricultural Research Service and the Colorado State University Agricultura Experiment Station. The authors wish to thank the Arapaho National Wildlife Refuge and all the support personnel for their assistance on the study.

Manuscript accepted 22 May 02.
Resumen

La erosión del suelo ha sido vinculada a la sedimentación de las corrientes de agua, la degradación de ecosistemas y la perdida de productividad de pastizales. Sin embargo, se carece de conocimiento de como la perdida de suelo afecta la productividad de los pastizales o la sostenibilidad del ecosistema. Evaluamos el efecto de 3 niveles de reducción de cobertura vegetal $(0,27$ y $43 \%)$ y remoción de suelo $\left(0,12\right.$ y 24 ton ha $\left.^{-1}\right)$ en el escurrimiento superficial y la producción de sedimento en una estepa de "Sagebrush" [Artemisia tridentata var. vasseyana (Rydb.) Beetle] bajo lluvia simulada. El tiempo de inicio del escurrimiento superficial fue afectado por los tratamientos de reducción de cobertura vegetal, pero no por los de remoción de suelo. El tratamiento de $\mathbf{4 3 \%}$ de reducción de cobertura vegetal resultó en un menor tiempo de iniciación del escurrimiento que el obtenido por los tratamientos de reducción de cobertura de 0 y $27 \%(P=0.002)$. Los resultados del análisis de covarianza indicaron que la reducción de la vegetación y la remoción del suelo no afectaron significativamente el rendimiento de sedimento o las cantidades escurrimiento en el primer año después de aplicados los tratamientos. El análisis de regresión múltiple reveló que la producción total de sedimento estuvo relacionada a la cobertura de hierbas, contenido de arena en el perfil superior del suelo $(0-5 \mathrm{~cm})$ y la cantidad de suelo desnudo. El tiempo de inicio del escurrimiento estuvo positivamente correlacionado con la pendiente. A pesar de la falta de diferencia significativa entre tratamientos nosotros no concluimos que estos tratamientos de remoción de suelo y reducción de vegetación no tuvieron efecto en la hidrología superficial del suelo y la producción de sedimento. Hay numerosos estudios que muestran una fuerte relación entre la reducción de vegetación y la erosión del suelo. Futuras investigaciones en este sitio pueden revelar efectos a largo plazo de los tratamientos que no fueron aparentes en los resultados del primer año.

(Buckhouse and Gaither 1982), and impair fish habitat (Binkley and Brown 1993). In addition to ecological impacts, soil erosion can lead to decreased rangeland productivity through the loss of organic matter and plant nutrients. A principle challenge for rangeland managers is to optimize forage production for herbivores without reducing the ecological integrity of rangelands or decreasing their societal benefits.

Not all erosion is a result of land mismanagement. Soil erosion is a natural process of dislodgment of soil particles from the surface and subsequent transport by water and wind (Brooks et al. 
1997). Erosion at a rate greater than 11.2 tonnes $\mathrm{ha}^{-1} \mathrm{yr}^{-1}$ exceeds the estimated rate at which most parent material weathers (McCormack and Young 1981). Accelerated erosion and changes in soil surface hydrology have been reported under conditions of reduced vegetation cover and altered soil structure (Sampson 1918, McCalla et al. 1984, Linse et al. 2001). Preventing accelerated soil erosion has been regarded as the key to maintaining rangeland ecosystem sustainability (Buckhouse and Gaither 1982). Land managers, however, do not have scientifically based evidence for the amount of vegetation cover necessary to maintain rangeland sustainability. The influence of soil surface degradation (i.e., removal of the soil " $A$ " horizon, changes in surface roughness, decreasing micro-channel sinuosity, soil compaction and previous soil erosion) on rangeland sustainability is even less understood.

To prevent soil erosion by water, it is necessary to maintain the soil surface in a condition that readily accepts water (Brooks et al. 1997). The soil "A" horizon often contains significant amounts of organic matter which improves infiltration and increases soil water holding capacity. Therefore, removal of the " $A$ " horizon can lead to increased erosion of underlying soil horizons (Pimentel et al. 1995). The effects of soil removal on soil surface hydrology and sediment yield from rangelands are not well understood and must be clarified before accurate soil loss thresholds are developed.

The purpose of this research project was to determine the effects of vegetation cover reduction and soil removal on soil surface hydrology and sediment yield in a big sagebrush [Artemisia tridentata var. vasseyana (Rydb.) Beetle] steppe ecosystem. The main hypotheses of this project were that (1) a $27 \%$ reduction in vegetation cover would not result in altered soil hydrology, (2) a $43 \%$ reduction in cover would result in increased runoff and sediment production, (3) soil removal of 12 tonnes ha ${ }^{-1}$ would not affect soil surface hydrology, and (4) soil removal of 24 tonnes $\mathrm{ha}^{-1}$ would result in increased runoff and sediment yield.

\section{Methods and Materials}

\section{Site Description}

Field experiments were conducted on an upland area of the Arapaho National Wildlife Refuge (ANWR), $15 \mathrm{~km}$ south of Walden, Colo. The ANWR is located in an intermountain glacial basin known as North Park and encompasses 10,037 hectares. The study site $\left(40^{\circ} 36^{\prime} 48.5^{\prime \prime} \mathrm{N}\right.$, $\left.106^{\circ} 16^{\prime} 29.6^{\prime \prime} \mathrm{W}\right)$ was grazed by livestock prior to being designated as a wildlife refuge in 1967 (Lanier 1999) and is representative of a sagebrush steppe ecosystem classified in good rangeland health. Current management of the research site is exclusion of livestock grazing, but includes winter grazing by 200-500 freeroaming Rocky Mountain Elk (Cervus elaphus canadensis, Erxleben).

The site is at an elevation of approximately $2,500 \mathrm{~m}$, receives an average annual precipitation of $240 \mathrm{~mm}$, and experiences an average of 30 consecutive frostfree days per year. Soils are listed as a cabin sandy loam in the subgroup Argic Cryoboroll. These soils are deep, well drained soils that formed in gravelly alluvium, and are underlain by gravelly sand at a depth of 50 to $100 \mathrm{~cm}$ (USDA 1981). The average soil texture was $61 \%$ sand, $22 \%$ silt, and $17 \%$ clay, but ranged from 55-64\% sand, $19-27 \%$ silt, and 14-25\% clay.

\section{Experimental Design}

The experimental design was a randomized complete block experiment with a $3 \mathrm{x}$ 3 factorial arrangement of treatments. The treatments consisted of 3 levels of soil removal $\left(0,12\right.$, and 24 tonnes ha $\left.{ }^{-1}\right)$ and 3 levels of plant canopy reduction $(0,27$, and $43 \%$ ) with 3 replications of each treatment (27 plots). Individual treatments were randomly assigned to pairs of plots. Each plot was paired with an adjacent plot of the same size according to similar vegetation characteristics and amount of bare ground. One of the plot pairs was used for destructive sampling (above ground biomass and soil bulk density) and the other plot was used for collecting sediment yield and runoff variables. The plots were located on a $7 \%$ slope within an exclosure area of approximately $5,000 \mathrm{~m}^{2}$.

\section{Plot Installation and Rainfall Simulator}

Plots measuring 2 × $0.6 \mathrm{~m}$ were delineated by inserting $15 \mathrm{~cm}$ wide metal sheets into the soil to a depth of $3-6 \mathrm{~cm}$ on the up-slope end and sides of each plot. Plot pairs, separated by one meter, were oriented lengthwise with the slope. Runoff collection troughs were placed at the downslope end of each plot and sealed against the soil surface with an expanding foam. Rainfall simulations took place during the period from 27 July 1999 to 5 August 1999. A rotating boom rainfall simulator developed by the University of Wyoming (Linse 1992) was used to apply simulated rainfall to plots at an intensity of $100 \mathrm{~mm}$ hour $^{-1}$ for 30 minutes (dry run) at antecedent soil moisture. After $30 \mathrm{~min}$ utes, the third of 3 spray nozzles was activated and water pressure was increased to apply rainfall at an intensity of $150 \mathrm{~mm}$ hour $^{-1}$ for an additional 30 minutes (wet run).

The rainfall intensity of $100 \mathrm{~mm}$ hour $^{-1}$ was chosen to simulate a high intensitylow frequency storm that would exceed the infiltration capacity and produce measurable runoff (Linse et al. 2001). The increased application rate, in the wet run, was used to determine whether sediment yield from this ecosystem was energy limited. Six wedge rain gauges were spaced at equal distances around the perimeter of each plot to measure the total amount of simulated rainfall that reached the plot during the dry and wet runs. Runoff samples were manually collected every 2 minutes, for a duration of 6 seconds, from each plot.

\section{Treatments}

Soil and vegetation treatments were applied in July 1999. Soil was vacuumed from plot surfaces using a gas-powered blo-vac. Soil was vacuumed from bare ground, coppice dunes, and through the crowns of all forb and grass plants to achieve a uniform soil removal. Vacuumed soil was field weighed and taken back to the lab to dry, obtain a more accurate weight, and determine particle size. Non-woody canopy cover was killed by spraying Roundup herbicide through one of 2 perforated board templates onto circular patch areas within the plots. The exposed area of template 1 represented $30 \%$ of the plot area. The exposed area of template 2 represented $60 \%$ of the plot area. However, vegetation cover reduction from these treatments averaged $27 \%$ and $43 \%$ for the $30 \%$ and $60 \%$ templates, respectively. Where shrub cover was exposed beneath the perforations, the shrub canopy was spray painted and removed with pruning shears. The resulting soil-vegetation characteristics were designed to represent variations in degraded rangeland sites.

\section{Plot Characterization}

Vegetation cover and soil surface roughness were measured before and after treatments were applied. Vegetation cover was estimated by individual species using the point frame method (Bonham 1989, Linse et al. 2001). A 2 × $0.6 \mathrm{~m} 100$ point hori- 
zontal plane pin table was placed onto each plot and pins were lowered until either vegetation, standing litter, rock, surface litter or bare ground was intercepted. The initial pin hit was used to determine canopy cover by species. As many as 2 pin hits were recorded to determine canopy cover of sagebrush and under story herbaceous species cover. Each pin was then lowered to the soil surface to characterize soil surface cover. Absolute canopy cover by species and absolute soil surface cover was recorded as the percentage of total pin strikes for that cover class per total pin strikes for the plot. Cover, by plant life form, and soil surface characteristics were categorized into 8 classes: grasses (by species), forbs (by species), shrubs (by species), standing litter (current year litter which had not fallen to the ground and standing woody debris), cryptograms, bare ground, rock, and litter. Surface roughness was measured using a digital caliper resting on top of the lowered pins. Surface roughness was calculated as the standard deviation of the elevation of 100 pins (Kuipers 1957, Linse et al. 2001). Finally, the hill slope $(\%)$ was calculated by determining the regression equation for the average slope of a plane of the plot as determined by pin height measurements.

In each destructively sampled plot, two, $192 \mathrm{~cm}^{3}$ soil samples were collected to a depth of $10 \mathrm{~cm}$. These samples were divided into 2 subsamples at $0-5 \mathrm{~cm}$ and $5-10 \mathrm{~cm}$ to determine soil bulk density using the core method (Blake and Hartge 1986) and soil texture according to the hydrometer method (Bouyoucos 1962). Immediately prior to each rainfall simulation, three, $51 \mathrm{~cm}^{3}$ soil cores were removed adjacent to the plot pair. These samples were divided into subsamples at $0-5 \mathrm{~cm}$ and $5-10 \mathrm{~cm}$ to determine antecedent soil moisture using the gravimetric method (Gardner 1986).

\section{Runoff Hydrograph}

Hydrographs were generated by plotting runoff values over time for dry and wet runs. The shape of the hydrograph was used to evaluate the time to runoff initiation, equilibrium runoff rate, and equilibrium runoff ratio (Frasier et al. 1998a). Time to runoff initiation was defined as the time when the runoff rate exceeded $5 \%$ of the rainfall rate. The equilibrium runoff period was defined as the time when the rising limb of the hydrograph leveled off until the end of the appropriate time period (dry or wet run). The equilibrium runoff ratio was defined as the average percentage of applied rainfall that was collected as runoff during the equilibrium runoff period and was calculated for the dry and wet runs.

\section{Sedigraph}

Every runoff sample was transferred to an individual sediment bottle until peak runoff was reached (determined as the point at which runoff leveled off or showed an initial decline). After the initial peak runoff rate was attained, every other runoff sample was transferred to a sediment bottle for subsequent sediment analysis. Prior to sediment filtration, paper filters with 1 micrometer pores were dried at $40^{\circ} \mathrm{C}$ for 4 hours and weighed. Sediment samples were gravity filtered and then dried for 6 hours at $80^{\circ} \mathrm{C}$ and weighed (Gutierrez-Castillo 1994). A sedigraph was generated by plotting sediment yield vs. time. The area under the curve of this graph was integrated to determine total sediment yield. Sediment yield is reported in $\mathrm{kg} \mathrm{ha}^{-1} \mathrm{~mm}$ runoff $\mathrm{f}^{-1}$. These units adjust sediment yield for the amount of runoff carrying the sediment to the trough. In addition to these parameters, sediment yield which occurred between the time to runoff initiation and the end of the dry run was subdivided into 3 periods (early, middle, and late).

\section{Data Analysis}

Data were analyzed using standard statistical programs (SAS Institute Inc. 1998) available for analysis of covariance (PROC GLM), multiple regression analysis (PROC REG), and repeated measures analysis of variance (PROC MIXED). Differences were considered significant at $\mathrm{P}<0.10$. Analysis of covariance was used to determine whether soil removal or vegetation reduction significantly affected runoff or sediment yield. Covariates included slope, antecedent soil moisture, soil bulk density, total live vegetation cover, sagebrush cover, litter cover, grass cover, forb cover, bare ground, soil texture, and surface roughness. Multiple linear regression, with stepwise selection, was used to determine whether significant relationships existed between independent variables (bare ground, grass cover, sagebrush cover, litter cover, total vegetation cover, sand, slope, soil bulk density, antecedent soil moisture, surface roughness, and rainfall intensity), and sediment yield or runoff values (SAS Institute Inc. 1998). The average sediment yield in each period was used in repeated measures analysis of variance to determine whether there was a significant decrease in sediment yield over time. Analysis of sedi- ment yield residual plots indicated the need for a natural logarithm (ln) transformation of these data. Therefore, all data in this study were analyzed using a ln transformation. This transformation was also used by Sharpley (1985) to analyze sediment yield.

\section{Results and Discussion}

\section{Vegetation and Soil Parameters}

Average pre-treatment vegetation canopy cover across all plots was $45 \%$, but ranged from 30 to $65 \%$. Average soil bulk density across plots was $1.22 \mathrm{~g} \mathrm{~cm}^{-3}$ in the upper $0-5 \mathrm{~cm}$ and $1.25 \mathrm{~g} \mathrm{~cm}^{-3}$ in the lower $5-10 \mathrm{~cm}$ of the soil profile. Soil bulk density was not significantly different among treatments.

Water erosion typically removes fines (clay- and silt-sized soil particles) and leaves coarse particles behind (Ellison 1944, 1948, Pearce et al. 1998). Although particles larger than clay and silt, and large soil aggregates, may be detached by raindrop splash, they settle out of the overland flow much sooner than finer particles (Ellison 1944, Pearce et al. 1998). The soil texture of the vacuumed soil was $65 \%$ sand, $22 \%$ silt and $13 \%$ clay, with ranges of $64-69 \%, 19-24 \%$, and $12-15 \%$, respectively. This texture was not statistically different from the in situ soil texture. This suggests that vacuuming of the surface soil did not selectively remove silt- and clay-sized particles, as would be expected under natural water erosion events. Although soil particle size was not affected by the vacuuming, the soil removal treatment did affect surface roughness. The average surface roughness of vacuumed plots (27 S.D.) was significantly greater $(P<0.001)$ than the average pretreatment surface roughness (22 S.D.).

\section{Runoff}

The amount of runoff is the difference between the amount of water applied minus the water retained on the soil and plant surfaces, and the amount that infiltrated into the soil (Frasier et al. 1998a). Three runoff parameters were analyzed: time to runoff initiation, equilibrium runoff ratio in the first 30 minutes (dry run) of the rainfall simulation, and equilibrium runoff ratio in the last 30 minutes (wet run) (Table 1).

In many rangeland situations, the runoff characteristics at the beginning of the storm, such as time to runoff initiation, are most important because storm durations are too short to develop equilibrium runoff 
Table 1. Means (standard errors) for runoff parameters by treatment from sagebrush steppe rainfall simulation plots. Treatment differences were not significant at $\mathrm{P}<0.10$.

\begin{tabular}{lcccc}
\hline \hline $\begin{array}{l}\text { Soil } \\
\text { Removal }\end{array}$ & $\begin{array}{c}\text { Vegetation } \\
\text { Reduction }\end{array}$ & $\begin{array}{c}\text { Time to } \\
\text { Runoff Initiation }\end{array}$ & $\begin{array}{c}\text { Equil. Runoff Ratio } \\
\text { for Dry Run }\end{array}$ & $\begin{array}{c}\text { Equil. Runoff Ratio } \\
\text { for Wet Run }\end{array}$ \\
\hline (tonnes ha $\left.{ }^{-1}\right)$ & $(\%)$ & (minutes) & $(\%)$ & $(\%)$ \\
0 & 0 & $8.3(2.7)$ & $34(8.7)$ & $59(7.5)$ \\
0 & 27 & $2.3(0.7)$ & $48(8.7)$ & $68(13.3)$ \\
0 & 43 & $4.3(1.3)$ & $45(13.9)$ & $67(9.8)$ \\
12 & 0 & $5.7(1.3)$ & $43(8.7)$ & $71(13.9)$ \\
12 & 27 & $3.7(0.7)$ & $45(11.0)$ & $65(6.9)$ \\
12 & 43 & $4.3(1.8)$ & $47(9.8)$ & $64(8.7)$ \\
24 & 0 & $6.3(2.9)$ & $50(11.5)$ & $78(9.8)$ \\
24 & 27 & $3.0(1.2)$ & $43(9.2)$ & $69(9.8)$ \\
24 & 43 & $5.7(1.8)$ & $30(6.4)$ & $63(2.3)$ \\
\hline
\end{tabular}

(Frasier et al. 1998a). Our results showed that time to runoff initiation was affected by the vegetation canopy reduction treatments, but not by the soil removal treatments. The $43 \%$ vegetation canopy reduction treatment resulted in a shorter time to runoff initiation than did the $27 \%$ and $0 \%$ canopy reduction treatments $(\mathrm{P}=0.002)$. Nyhan et al. (1984) and Giordanengo (2001) found that antecedent soil moisture had a pronounced effect on time to runoff initiation. However, their results were from consecutive rainfall simulations that occurred over successively wet conditions on the same plots. In this study, antecedent soil moisture did not vary great enough from plot to plot to affect runoff variables.

Equilibrium runoff rates have been used as indicators of treatment differences in previous rainfall simulation studies (Simanton et al. 1991, Frasier et al. 1998b). Equilibrium runoff occurs when soil surface layers are saturated and is representative of long duration precipitation events that exceed the infiltration rate (Frasier et al. 1998b). Because equilibrium runoff rates are influenced by rainfall intensity, we used equilibrium runoff ratios [(runoff rate divided by rainfall rate) $x$ 100] to compare treatment effects. Equilibrium runoff ratios in the dry and wet runs were not significantly affected by treatments $(P=0.732$ and 0.872 , respectively). These results support findings by Busby and Gifford (1981), who reported that removal of vegetation did not have an immediate effect on infiltration.

Because the herbicide-treated dead vegetation cover was not removed prior to rainfall simulations, the standing litter that remained was likely affecting rainfall interception in the same manner as live vegetation. In addition, the vegetation treatments most likely did not have an affect on channel formation. Although not measured, it can be expected that over time, that regrowth of vegetation in the herbicide-treated areas may help to maintain the degree of channel formation present at the time of rainfall simulations. Unless annual treatments are applied, the desired degraded rangeland conditions may not be maintained, and it is unlikely that long term effects from these vegetation treatments will be noticeable.

Past research has shown that amount of slope (Wischmeier and Smith 1978, Sharpley 1985) and bare ground (Branson and Owen 1970, Wischmeier and Smith 1978) were positively correlated with runoff. However, our results indicated that slope and bare ground were not significant covariates and did little to explain treatment differences in runoff data. Other covariates that were used, but did not significantly affect equilibrium runoff ratios, included total live vegetation cover, sagebrush cover, grass cover, litter cover, surface roughness, antecedent soil moisture, and soil bulk density. Soil bulk density only represented bare interspace areas and did not vary significantly enough among treatments to influence runoff. The absolute cover of vegetation may not be as important a covariate as the spatial distrib-

Table 2. Means (standard errors) for sediment yield parameters by treatment from sagebrush steppe rainfall simulation plots. Treatment differences were not significant at $P<0.10$.

\begin{tabular}{|c|c|c|c|c|c|c|}
\hline \multirow{2}{*}{$\begin{array}{l}\text { Soil } \\
\text { Removal }\end{array}$} & \multirow{2}{*}{$\begin{array}{l}\text { Vegetation } \\
\text { Reduction }\end{array}$} & \multicolumn{5}{|c|}{ Sediment Yield } \\
\hline & & Total & $1^{\text {st }} 10$ Minutes & Dry Run & \multicolumn{2}{|c|}{ Wet Run } \\
\hline (tonnes ha ${ }^{-1}$ ) & $(\%)$ & - & $\mathrm{g} \mathrm{ha}^{-1} \mathrm{~mm}$ runo & - & & \\
\hline 0 & 0 & $761 \quad(429)$ & $218 \quad(111)$ & $461 \quad(234)$ & 300 & $(217)$ \\
\hline 0 & 27 & $4506(2823)$ & $1124(572)$ & $2439(1420)$ & 2067 & (1404) \\
\hline 0 & 43 & $685 \quad(332)$ & $256 \quad(135)$ & 434 (218) & 244 & (122) \\
\hline 12 & 0 & $(77)$ & $(48)$ & $443 \quad(37)$ & 393 & (114) \\
\hline 12 & 27 & $(167)$ & $(80)$ & $(176)$ & 397 & $(44)$ \\
\hline 12 & 43 & $(616)$ & $(165)$ & $(285)$ & 871 & $(422)$ \\
\hline 24 & 0 & (1776) & $(206)$ & $(974)$ & 1070 & (804) \\
\hline 24 & 27 & (97) & $(44)$ & (83) & 250 & $(57)$ \\
\hline 24 & 43 & $(456)$ & 335 (113) & $(263)$ & 499 & (232) \\
\hline
\end{tabular}

ution of the vegetation over the plot. The spatial distribution of vegetation influences the microchannel network which, in turn, may have dominated the runoff processes in this study.

The equilibrium runoff ratio, averaging all treatments, was significantly greater $(\mathrm{P}$ $<0.0001)$ in the wet run $(67 \%)$ than in the dry run $(43 \%)$. In addition to the increase in rainfall intensity, surface sealing of these soils may account for the increased runoff ratio (Farres 1978). Also, saturation of surface litter, plant surfaces and soil macropores would result in an increased proportion of rainfall reaching the soil surface and a decrease in infiltration.

\section{Sediment Yield}

There was an interaction between soil and vegetation treatments $(P=0.096)$ for total sediment yield. A $27 \%$ vegetation reduction resulted in greater sediment yield, at the soil removal level of 0 tonnes $\mathrm{ha}^{-1}$, than did a 0 or $43 \%$ vegetation reduction. Analyses of sediment data were done by soil treatment, averaging over vegetation treatment, and visa versa. Four sediment yield parameters were analyzed: total sediment yield over the $60 \mathrm{~min}$ rainfall simulation, sediment yield over the first 10 min, sediment yield for the dry run, and sediment yield for the wet run (Table 2).

Analysis of covariance indicated that total sediment yield was not significantly affected $(\mathrm{P}=0.441)$ by soil or vegetation treatments. Likewise, sediment yield in the first 10 minutes $(P=0.469)$, first 30 minutes $(\mathrm{P}=0.624)$, and last 30 minutes $(\mathrm{P}=$ 0.229 ) after rainfall simulations began was not significantly affected by soil or vegetation treatments. Given the slow decomposition rates in this arid environment, the roots and shoots of herbicide-treated plants should have been intact when the rainfall simulations occurred. Therefore, the indirect effects of vegetation on sedi- 
ment yield (i.e., increased litter cover, reduced bulk density and increased infiltrability), reported by Wilcox et al. (1988), was probably operating during rainfall simulations. In fact, our results indicated that an instantaneous reduction of live vegetation cover did not significantly affect runoff or sediment yield. Research by Busby and Gifford (1981) and Wilcox et al. (1988) has also shown that vegetation removal does not immediately affect infiltration or runoff. Similarly, Johnson and Gordon (1988) reported that sagebrush canopy removal did not significantly affect soil loss. If rainfall interception, infiltration, runoff and channel sinuosity are not being affected by vegetation treatments, then sediment yield will most likely not be altered. A more drastic change in vegetation cover, not just an aboveground kill, is likely necessary to influence sediment yield.

The effect of soil removal on subsequent sediment yield is not well documented. Results of this study did not support the hypothesis that soil removal of 24 tonnes $\mathrm{ha}^{-1}$ would result in increased sediment yield. One possible explanation is that the significant increase in surface roughness created by the soil vacuuming reduced sediment movement down slope. However, Linse et al. (2001) reported a weak correlation between surface roughness and sediment yield. The spatial variability of surface roughness, as opposed to an absolute value, may be a more accurate predictor of sediment yield. Linse (1992) explained how the spatial variability of surface roughness can affect sediment yield. If surface roughness is greater at the bottom of the plot, it may act to trap sediment from the top of the plot, whereas surface roughness concentrated at the upslope end of the plot will not trap as much sediment before it reaches the collection trough. Also, if surface roughness is interconnected along one side of the plot, the depressions may join to form a microchannel or rill. This may allow for considerable erosion from the plot. Using the point-frame method to measure surface roughness, it is possible to describe the spatial variability of surface roughness, but without quantifying the spatial arrangement of vegetation within the topography (e.g., degree of channel formation). Such an analysis is incomplete.

Sediment yield in runoff water generally decreases over time during a rainfall event (Ellison 1944, Gutierrez-Castillo 1994). Contrary to their findings, results from the repeated measures analysis of variance in this study revealed an increase in sediment yield over time $(P<0.001)$. Sediment yield in the late period was significantly greater than in the early period $(\mathrm{P}<0.001)$ and the middle period $(\mathrm{P}=0.024)$. This may be an indication that soil erosion in this sagebrush steppe is not a source-limited process. As such, removal of 24 tonnes $\mathrm{ha}^{-1}$ may not be drastic enough to affect subsequent sediment yield. This may help to explain the absence of significant differences in sediment yield among the soil removal treatments.

\section{Predicting Runoff and Sediment Yield \\ Runoff}

Three runoff parameters were analyzed: time to runoff initiation, equilibrium runoff ratio in the dry run, and equilibrium runoff ratio in the wet run. Independent variables included total vegetation cover $(\%)$, forb cover $(\%)$, grass cover $(\%)$, sagebrush cover $(\%)$, litter cover $(\%)$, bare ground $(\%)$, rainfall intensity $(\mathrm{mm} / \mathrm{hr})$, slope (\%), surface roughness (SD), sand in the upper $5 \mathrm{~cm}$ of the soil profile (\%), and soil bulk density $\left(\mathrm{g} / \mathrm{cm}^{3}\right)$. Results of the multiple regression analysis indicated that time to runoff initiation was positively correlated with slope $\left(\mathrm{R}^{2}=0.39, \mathrm{P}=\right.$ 0.005 , Table 3$)$. Other researchers (Flenniken 1999) have reported a correlation between time to runoff initiation and rainfall intensity. In our study, rainfall intensity was not correlated with time to runoff initiation, but did show a positive correlation with the dry run equilibrium runoff ratio $\left(\mathrm{R}^{2}=0.34, \mathrm{P}=0.002\right)$. Equilibrium runoff ratio in the wet run was not correlated with any of the independent variables used in the multiple regression analysis. Variables such as the spatial distribution of microtopography, channel sinuosity, and average infiltrability for each plot may be controlling runoff to a greater degree than the independent variables used in this analysis.

\section{Sediment Yield}

Many researchers (Meeuwig 1969, McCalla et al. 1984 and Linse et al. 2001) have documented changes in sediment yield with changes in litter cover, vegetation cover, bare ground, and surface roughness. In our study, total sediment yield was negatively correlated with forb cover $(P=0.018)$ and the amount of sand in the upper $5 \mathrm{~cm}$ of the soil profile $(\mathrm{P}=$ $0.016)$, and positively correlated with bare ground $(\mathrm{P}=0.055)$ for a model $\mathrm{R}^{2}$ of 0.60 (Table 3). Sediment yield in the first 10 minutes also showed a negative correlation with forb cover $(\mathrm{P}=0.011)$ and sand in the upper $5 \mathrm{~cm}$ of the soil profile $(\mathrm{P}=$ 0.014 ), for a model $R^{2}$ of 0.56 . The negative correlation between sand in the upper $5 \mathrm{~cm}$ of the soil profile and sediment yield may be attributed to the fact that sandier soils experience higher infiltration rates which results in a lower volume of overland flow. This lower overland flow provides a lower capacity for carrying soil particles and lower energy for dislodging soil particles as it moves down slope. In addition, sand particles are more difficult to transport down slope compared to finer grained particles such as silt or clay.

Bare ground was not strongly correlated with any of the sediment yield parameters analyzed (e.g., partial $\mathrm{R}^{2}$ values were 0.13 and 0.14 for total sediment yield and sediment yield in the wet run, respectively). Branson and Owen (1970) also reported a low correlation between bare ground and sediment yield ( $\mathrm{R}^{2}$ of 0.03 to 0.24 ). Some researchers, however, have reported highly positive correlations between bare ground and sediment yield (Hofmann et al. 1983). The lack of correlation in this study may have resulted from differences in the

Table 3. Results of stepwise multiple regression analysis for sediment and runoff variables from sagebrush steppe rainfall simulation plots.

\begin{tabular}{|c|c|c|c|c|c|c|}
\hline \multirow[b]{2}{*}{ Dependent Variables } & \multicolumn{5}{|c|}{ Partial $\mathrm{R}^{2}$ Values for Independent Variables } & \multirow[b]{2}{*}{$\begin{array}{c}\text { Model } \\
\mathrm{R}^{2}\end{array}$} \\
\hline & Slope & $\begin{array}{l}\text { Forb } \\
\text { Cover }\end{array}$ & $\begin{array}{c}\text { Sand } \\
(0-5 \mathrm{~cm})\end{array}$ & $\begin{array}{c}\text { Bare } \\
\text { Ground }\end{array}$ & $\begin{array}{l}\text { Rainfall } \\
\text { Intensity }\end{array}$ & \\
\hline & $(\%)$ & $(\%)$ & $(\%)$ & $(\%)$ & $\left(\mathrm{mm} \mathrm{hr}^{-1}\right)$ & \\
\hline \multicolumn{7}{|l|}{ Sediment $\left(\mathrm{kg} \mathrm{ha}^{-1} \mathrm{~mm}\right.$ runoff $\left.^{-1}\right)$} \\
\hline Total & - & 0.15 & 0.32 & 0.13 & - & 0.60 \\
\hline First $10 \mathrm{~min}$ & - & 0.34 & 0.22 & - & - & 0.56 \\
\hline First $30 \mathrm{~min}$ & - & - & 0.29 & - & - & 0.29 \\
\hline Second $30 \mathrm{~min}$ & - & 0.11 & 0.31 & 0.14 & 0.11 & 0.67 \\
\hline \multicolumn{7}{|l|}{ Runoff } \\
\hline Time to runoff $(\mathrm{min})$ & 0.39 & - & - & - & - & 0.39 \\
\hline Equil. Runoff Ratio (dry run) & - & - & - & - & 0.34 & 0.34 \\
\hline Equil. Runoff Ratio (wet run) & - & 一 & 一 & - & - & - \\
\hline
\end{tabular}


spatial distribution of bare ground from plot to plot. If bare ground dominates the lower portion of the plot, significant channeling may form throughout the rainfall simulation, allowing high sediment yields to occur. However, if bare ground is randomly distributed in small patches across the plot, then significant sediment yield will be unlikely given the lack of connectivity between areas of higher erosion potential and low channel formation. Even if bare ground is dominating the up-slope portions of the plot, the remaining vegetation at the down-slope end of the plot can be effective at creating pools and allowing sediment to settle out of the runoff before water leaves the plot. In addition, the upslope end of the plot should experience lower runoff volumes than the down-slope portions of plots.

\section{Variability of Runoff and Sediment Yield Parameters}

Spatial variability in infiltration rates and erosion have been reported by Ellison (1945), Gard and Van Doren (1949), and Nyhan et al. (1984). The spatial variability in soil characteristics, flow paths, depth to parent material and infiltration rates over this seemingly uniform range site probably masked any real treatment effects on the small plots. During rainfall simulation events, qualitative observations revealed significant ponding where the borders of the plots intersected sagebrush dunes. Plot borders may create artificial ponds and interrupt flow paths to a greater degree in small narrower plots than in large wider plots. Therefore, the edge effect may be lower in large plots than in small plots. In addition, larger plots should integrate more spatial heterogeneity of soil and plant characteristics, which influence runoff and sediment variability.

\section{Summary and Conclusions}

Rainfall simulations were conducted within 1 month after vegetation reduction and soil removal treatments were applied. Results within this short period indicated that soil removal and vegetation reduction treatments did not significantly affect total runoff, equilibrium runoff ratios, or any of the sediment yield parameters analyzed. However, from these short-term results, we do not conclude that vegetation reduction and soil removal will not eventually influence runoff and sediment yield. Future research at this site may reveal long-term treatment effects that were not apparent in first year results.
Because rainfall events in this sagebrush steppe are typically of short duration, measurable parameters such as time to runoff initiation and sediment yield within 10 minutes after rainfall initiation have practical value for land managers. Time to runoff initiation was significantly affected by the $43 \%$ vegetation reduction treatment, supporting findings of previous research and strengthening the argument for grazing intensities which do not reduce vegetation cover beyond this point. However, determining a vegetation reduction threshold would, at the very least, require a finer gradation of vegetation reduction treatments.

Almost half of the variability in sediment yield is unexplained by the independent variables measured in this study, making a meaningful prediction model difficult to obtain. Despite some statistically significant multiple regression results, we can not conclude that factors affecting sediment yield in the first 10 minutes (ie., forb cover and sand in the upper soil profile) would be reliable field indicators of erosion potential in this ecosystem. While the negative correlation between sand in the upper soil profile and sediment yield was an intuitive result, interpreting the negative correlation between forb cover and sediment yield was not attempted. Though this correlation was statistically significant, further research is necessary to confirm that such a correlation is ecologically valid.

Soil surface and vegetation parameters are inherently variable in sagebrush steppe and other plant communities. Many of these parameters, such as connectivity of flow paths, are difficult to quantify and may greatly influence results. Without quantifying the connectivity of flow paths, researchers employing rainfall simulators will continue to be challenged to find treatment differences as influenced by vegetation cover and soil parameters. Future studies should consider quantifying flow path connectivity, increasing replications and improving blocking structure to more accurately determine the factors that control runoff and erosion processes in sagebrush steppe rangelands.

\section{Literature Cited}

Bills, N.L. and R.E. Heimlich. 1984. Assessing erosion on U.S. cropland: land management and physical features. USDA, Econ. Res. Serv., Natur. Resource Econ. Div. Agr. Econ. Rep. No. 513.
Binkley, D. and T.C. Brown. 1993. Management impacts on water quality of forests and rangelands. USDA For. Ser. Gen. Tech. Rep. RM-239. Ft. Collins, Colo.

Blake, G.R. and K.H. Hartge. 1986. Bulk density, pp. 363-375. In: A. Klute (ed.) Methods of Soil Analysis, Part 1, Physical and Mineralogical Methods. $2^{\text {nd }}$ ed. No. 9 Agron. Amer. Soc. Agron., Madison, Wis.

Bonham, C.D. 1989. Measurements for Terrestrial Vegetation. John Wiley and Sons, Inc., New York, N.Y.

Bouyoucos, G.J. 1962. Hydrometer method improved for making particle size analysis of soil. Agron. J. 54:464-465.

Branson, F.A. and J.B. Owen. 1970. Plant cover, runoff, and sediment yield relationships on Mancos Shale in Western Colorado. Water Resources Res. 6:783-790.

Brooks, K.N., P.F. Ffolliott, H.M. Gregersen, and L.F. DeBano. 1997. Hydrology and the Management of Watersheds, $2^{\text {nd }}$ ed., Iowa State Univ. Press, Ames, Iowa.

Buckhouse, J.C. and J.L. Gaither. 1982. Potential sediment production within vegetative communities in Oregon's Blue Mountains. J. Soil and Water Cons. 37:120-122.

Busby, F.E. and G.F. Gifford. 1981. Effects of livestock grazing on infiltration and erosion rates measured on chained and unchained pinyon-juniper sites in Southeastern Utah. J. Range Manage. 34:400-405.

Ellison, W.D. 1944. Studies of raindrop erosion. Agr. Eng. April:131-136.

Ellison, W.D. 1945. Some effects of raindrops and surface-flow on soil erosion and infiltration. Amer. Geophy. Union Trans. 26:415-429.

Ellison, W.D. 1948. Erosion by raindrop. Sci. Amer. 179:40-45

Farres, P. 1978. The role of time and aggregate size in the crusting process. Earth Surf. Processes 3:243-254.

Flenniken, M. 1999. Flow characteristics and sediment movement in a montane riparian ecosystem. M.S. Thesis, Colorado State Univ., Fort Collins, Colo.

Frasier, G.W., M. Weltz, and L. Weltz. 1998a. Technical Note: Rainfall simulator runoff hydrograph analysis. J. Range Manage. 51:531-535.

Frasier, G.W., M.J. Trlica, W.C. Leininger, R.A. Pearce, and A. Fernald. $1998 b$. Runoff from simulated rainfall in 2 montane riparian communities. J. Range Manage. 51:315-322.

Gard, L.E. and C.A. Van Doren. 1949. Soil losses as affected by cover, rainfall, and slope. Soil Sci. Soc. Amer. Proc. 14:374-378.

Gardner, W.H. 1986. Water content, pp. 493-544. In: A. Klute (ed.) Methods of Soil Analysis, Part 1, Physical and Mineralogical Methods. $2^{\text {nd }}$ Ed. No. 9 Agron. Amer. Soc. Agron. J., Madison, Wis.

Giordanengo, J.H. 2001. Hydrologic and Soil Erosion Responses to Soil Removal and Vegetation Reduction. M.S. Thesis, Colorado State Univ., Fort Collins, Colo. 
Gutierrez-Castillo, J. 1994. Infiltration, sediment, and erosion under grass and shrub cover in the southern high plains. Ph.D. Diss., Texas Tech Univ., Lubbock, Tex.

Hofmann, L., R.E. Ries, and J.E. Gilley. 1983. Relationship of runoff and soil loss to ground cover of native and reclaimed grazing land. Agron J. 75:599-602.

Johnson, C.W. and N.D. Gordon. 1988. Runoff and erosion from rainfall simulator plots on sagebrush rangeland. ASAE Trans. 31:421-427.

Kuipers, H. 1957. A reliefmeter for soil cultivation studies. Neth. J. Agr. Sci. 5:255-262.

Lanier, M. 1999. Facsimile correspondence. United States Dept. of the Interior, Fish and Wildl. Serv., Arapaho Nat. Wildl. Refuge, Walden, Colo.

Linse, S.J. 1992. The influence of ground cover on upland range erosion. M.S. Thesis, Univ. Wyoming, Laramie, Wyo.

Linse, S.J., D.E. Mergen, J.L. Smith, and M.J. Trlica. 2001. Upland erosion under a simulated most damaging storm. J. Range Manage. 54:356-361.

McCalla II, G.R., W.H. Blackburn, and L.B. Merrill. 1984. Effects of livestock grazing on sediment production, Edwards Plateau of Texas. J. Range Manage. 37:291-294.
McCormack, D.E. and K.K. Young. 1981. Technical and societal implications of soil loss tolerance, pp. 365-376. In: Soil Conservation-Problems and Prospects. John Wiley \& Sons, New York, N.Y.

Meeuwig, R.O. 1969. Infiltration and soil erosion as influenced by vegetation and soil in northern Utah. J. Range Manage. 23:185-189.

Meyers, N. 1984. Gaia: An Atlas of Planet Management. Anchor Press/Doubleday and Company Inc., Garden City, N.Y.

Nyhan, J.W., G.L. DePoorter, B.J. Drennon, J.R. Simanton, and G.R. Foster. 1984. Erosion of earth covers used in shallow land burial at Los Alamos, New Mexico. J. Environ. Qual. 13:361-366.

Pearce, R.A., M.J. Trlica, W.C. Leininger, D.E. Mergen, and G.W. Frasier. 1998. Sediment movement through riparian vegetation under simulated rainfall and overland flow. J. Range Manage. 51:301-308.

Pimentel, D.C., H.P. Resosudarmo, K. Sinclair, D. Kurz, M. McNair, S. Crist, L. Shpritz, L. Fitton, R. Saffouri, and $R$. Blair. 1995. Environmental and economic costs of soil erosion and conservation benefits. Sci. 267:1117-1123.
SAS Institute Inc. 1998. SAS Procedures Guide, Version $6,3^{\text {rd }}$ ed., SAS Institute Inc., Cary, N.C.

Sampson, A.W. 1918. Range preservation and its relation to erosion control on western grazing lands. USDA Bull. 675. USDA, Wash., D.C.

Sharpley, A.N. 1985. Depth of surface soilrunoff interaction as affected by rainfall, soil slope, and management. Soil Sci. Soc. Amer. J. 49:1010-1015.

Simanton, J.R., M.A. Weltz, and H.D. Larsen. 1991. Rangeland experiments to parameterize the water erosion prediction project model: vegetation canopy cover effects. J. Range Manage. 44:276-282.

USDA - Soil Conservation Service (SCS). 1981. Soil Survey of Jackson County area, Colo., U.S. Gov. Print. Off., Wash., D.C.

Wilcox, B.P., M.K. Wood, and J.M. Tromble. 1988. Factors influencing infiltrability of semiarid mountain slopes. J. Range. Manage. 41:197-206.

Wischmeier, W.H. and D.D. Smith. 1978. Predicting rainfall erosion losses - a guide to conservation planning. USDA Agr. Handb.. No. 537. USDA, Sci. and Ed. Admin., U.S. Gov. Print. Off., Wash. D.C. 